\title{
Provocation
}

\section{Beyond multiculturalism: A journey to nowhere?}

\section{len Ang}

If there is such a thing as a 'crisis of multiculturalism' today, what does that crisis consist of? And how can it be resolved? Can there be a renewed 'multiculturalism' for the twenty-first century and, if so, what will this mean for museums?

Many have blamed the corrosion of Australia's proud multicultural credentials, which were especially strong in the 1980s and early 1990s, on former Prime Minister John Howard, who made the ' $\mathrm{M}$ ' word virtually unspeakable when he came to power in 1996. Indeed, for Howard, multiculturalism was an unwelcome and objectionable assault on time-honoured notions of Australian national identity, which for him should have remained firmly rooted in traditional Anglo-Australian history and values. Australia might have become more culturally diverse as a result of many decades of mass immigration, but this should not, from Howard's perspective, detract from the overriding significance of a homogeneous Australian cultural nationalism as the guarantor of national unity and civic loyalty. Multiculturalism, in this regard, was a divisive ideology that encouraged migrants to maintain their cultural separateness rather than integrating into the Australian mainstream. Its emphasis on difference and diversity flew in the face of the desire for cohesive and unified nationhood.

The Howard Government's distaste for multiculturalism was clearly at work, as widely commented on (including in several essays in this issue), in the infamous row about the National Museum of Australia (NMA) in 2001. The NMA quickly became embroiled in Howard's culture war and, in the aftermath of the 2003 review of the museum's exhibitions and public programs, one of the significant casualties was Horizons, the permanent exhibition dedicated to the history of immigration and multiculturalism in Australia. Narrating 'the peopling of Australia since 1788', Horizons told the story through a kaleidoscopic range of objects such as a traditional Castellorizian costume worn by a Greek migrant, an English settler's toy farmyard set, crockery from a convict housewife's kitchen and an Italian barber's shaving tools - the familiar stories of migrants and their rather quaint objects of diasporic memory. The exhibition also, however, evoked the darker side of the story of Australian immigration, represented most notoriously by the White Australia Policy, which pointed to the intrinsically political nature of the nation's history of settlement since the arrival of the British: the attempt to create an exclusively white nation-state by keeping undesirable 
non-whites out (and by 'whitewashing' the blacks within). This history also implicitly referred to the radically transformative nature of multiculturalism as a new policy framework that emerged in the 1970s: the transition from 'white Australia' to 'multicultural Australia' (where racial, ethnic and cultural diversity was held as normative) was indeed a momentous one, or at least it was represented as such.

Howard's review committee recommended the scrapping of Horizons because its 'black-armband' view of immigration history did not sufficiently contribute to a coherent narrative of national progress. It was recently replaced by a new permanent exhibition, Australian Journeys. I shall return to this new exhibition, but first, let me go back to this much-maligned idea of multiculturalism. Now that Howard has gone, what should we make of it? Is it dead? Or can it be resurrected now that we have a Labor government, whose attitudes to cultural diversity and to ethnic minority rights might be expected to be more sympathetic? We shouldn't be too optimistic. To date, there is no reference whatsoever to 'multiculturalism' on the Australian Labor Party's official web site; there is a distinct lack of new thinking and leadership in this area. Yes, the government has affirmed its conviction that 'religious and cultural diversity is a permanent and valuable feature of Australian society' and it recently has established an Australian Multicultural Advisory Council, whose composition is said to 'reflect that diversity'. ${ }^{1}$

The articulated role of this council is, however, hardly a departure from the kinds of emphases the Howard Government introduced. In the words of Senator Chris Evans, Minister for Immigration and Citizenship: 'The new council will advise the government on practical approaches to promoting social cohesion, the engagement of migrants in Australian society, overcoming racism and intolerance and communicating to the public on this complex social policy area. ${ }^{2}$ The overall aim - social cohesion - remains the same. What is different-and this is welcome - seems to be a recognition that racism and intolerance are problems that need to be addressed and, perhaps most importantly, the explicit admission that this social policy area is 'complex'.

So where does this leave us? I have to say that I am not surprised. The world over, 'multiculturalism' has now lost its power to appeal to our imagination. This isn't because what it stands for is no longer important, but because the conditions in which it has to make its impact have become, well, so much more complex. As a practical policy of social inclusion and diversity management, it is still of immense importance at a local level - in neighbourhoods, schools, health care, and so on - where the need to respond to diverse constituencies is simply unavoidable. As the fragmenting and disorienting effects of globalisation deepen, however - signposted by dramatic events such as the terror attacks of 11 September 2001 and, most recently, the global financial crisis-longings for 
national unity and integration (however imaginary) have become more emphatic even as there is a universal admission that our world is irrevocably one of global interdependence and interconnectedness, where the transnational mobility of people is set to increase despite the intensification of border control regimes and the like.

In this context, it is impossible for us to return to the 'multiculturalism' of the early 1990s, a seemingly more unencumbered time when the celebration of multicultural diversity could be posed as an unambiguous sign of national progress, a thorough repudiation of the nation's white assimilationist past. Today, however, Australia as a nation is vastly more de facto multicultural than 15 years ago, but at the same time the nation's diversity is also more multi-layered, more internally contradictory, more brittle and dynamic, more entangled within webs of transnational links and tensions. Migrants today come from a vastly greater range of countries and they come for many more different purposes. Many of them do not settle permanently but come and go as they pursue opportunities elsewhere or as their visas expire. Ethnicity, which was supposed to signify the collective difference of migrants in the era of high multiculturalism, is no longer what it used to be; migrant identities are now much more mutable, differentiated and individualised. This dynamic, hyper-diverse reality can no longer be captured by the singular term 'multiculturalism' with its rather static connotation of coexisting but mutually exclusive cultural communities. What can replace it?

The NMA's new permanent exhibition, Australian Journeys, simply evades this question. Unlike Horizons, it doesn't feature the themes of inclusion and exclusion that are associated with Australia's history of immigration and multiculturalism. Instead, the emphasis in the new gallery is on cosmopolitanism: on Australia's interconnections with the world. As the NMA web site puts it, 'Australian Journeys explores the personal stories of migrants, travellers and traders and how their objects have connected places in Australia with places abroad.' It features 'journeys of people to and from Australia and the social, political and economic impacts of those journeys'.

A great deal of the exhibit is dedicated to nineteenth-century voyages of European explorers, including Captain James Cook, and details the experiences of people who travelled to and from the Australian colonies in the nineteenth century. We are given a global view of the history of tea: 'By 1770 a sip of tea connected an English family to the spice ports of Java, the sugar plantations of the West Indies and the tea gardens and potteries of China.' We are also, however, served with more familiar stories of migrants from different corners of the world such as Italy, Ireland, Morocco, Vietnam, Latvia and Germany throughout the twentieth century. One particularly poignant story features a group of Indonesian independence activists who brought their gamelan digul to Melbourne during 
World War II. We are casually told, in the accompanying written narrative, that these Indonesians were subjected to the infamous White Australia Policy dictation test after the war, and subsequently deported. This story of exclusion sits side by side with more uplifting stories such as cricketing journeys to and from Australia, successful trade ventures such as the Kuta Lines surfwear company, whose designs were inspired by Balinese textiles, and the trip of two Wik sculptures, Wallaby and Shark, to America in 1988, organised by curator Peter Sutton of the South Australian Museum. These exemplify the stories of sportsmen and women, artists and scientists working on the world stage in the twenty-first century'.

This is a gallery fit for twenty-first-century consciousness: the idea that no nation is an island, but is shaped fundamentally by continuing flows in and out of people and whatever they bring with them on their journeys. The outlook is transnational: visitors are encouraged to see that Australia's history is thoroughly entangled with that of other parts of the world, that its boundaries have always been porous - and all the better for it!

I must say that I felt strangely deflated after seeing Australian Journeys. Yes, I believe that in this globalised age it is important for a national museum of Australia to represent the nation's irrevocably hybrid make-up and to promote a cosmopolitan vision of and for the nation. Here, however, we are presented with such an eclectic array of stories, objects and images that what we are left with is the dominant impression of a cheerful, kaleidoscopic pluralism in which substantive differences are flattened out. By merging migrants, traders and travellers into a singular category of people and objects on the move, the peculiarity of Australia's immigration history - in social, geographical and political terms - disappears from view. The result is a depoliticised representation of cultural diversity, shaped by a virtually unhindered mobility in which Australia's cosmopolitan connections seem limitless and unproblematic.

As much as I didn't like Horizons because it presented the history of immigration into this country in an overly didactic way, relying too unreflexively on the values and approaches of 1990s multiculturalist orthodoxy, with Journeys, we can see the pendulum swinging too much to the other side. The very inclusive globality of Journeys, encompassing as it does people flows of all kinds and in all directions without distinction, results in a downplaying of the very real role of barriers, borders and biases in the active restriction of movements into Australia - the isolated and decontextualised story of the Indonesian gamelan troupe's expulsion notwithstanding. The expansive focus of Journeys on flows in and out of the nation magically dissolves the tension between unity and diversity, which was so central to the problematic concern of multiculturalism, and which multiculturalism itself sought unsuccessfully to overcome. 
With Journeys, then, the NMA's solution to the crisis of multiculturalism has been one of turning the Australian nation prematurely transnational and boundlessly cosmopolitan. Within the space of the nation, however, the experience of difference as difficulty as well as creativity, and the complexities of multicultural coexistence that go hand in hand with the story of immigration-led nation-building, remain sources of storytelling that deserve to be represented, not for reasons of 'political correctness' but for the simple reason that it is crucial for our national self-understanding, for an enhanced conversation about how Australians - in all their complex, fluid and unequal diversity-live together, and with the world. The NMA knows this, of course, and in the past years it has staged several exhibitions in its Nation Focus Gallery that feature 'migrant' topics, such as Migration Memories in 2007, Selling an American Dream: Australia's Greek café in 2008 (about the role of Greek Australians in introducing Americanised eating and popular cultural habits in Australia) and, most recently, an exhibition celebrating more than 40 years of Turkish migration to Australia (2009). These are all worthy initiatives, yet the very fact that they are temporary exhibitions implicitly sends the message that these are not stories of general national significance; instead, they tend to address special groups and communities. Once again, then, multicultural issues are relegated to the margins of minority interest, strictly separated from the mainstream. In institutionalising this bifurcation, the NMA perpetuates a dualism that was at the base of the crisis of multiculturalism in the first place.

\section{ENDNOTES}

1 Australian Labor Party 2008, Multicultural experts to further Australia's strength in diversity, Media statement, 17 December 2008.

2 Ibid. 